\title{
De maakbare behoefte : naar een filosofie van duurzame ontwikkeling
}

Citation for published version (APA):

van Lente, H. (2010). De maakbare behoefte : naar een filosofie van duurzame ontwikkeling. Datawyse / Universitaire Pers Maastricht. https://doi.org/10.26481/spe.20101012hl

Document status and date:

Published: 12/10/2010

DOI:

10.26481/spe.20101012hl

Document Version:

Publisher's PDF, also known as Version of record

\section{Please check the document version of this publication:}

- A submitted manuscript is the version of the article upon submission and before peer-review. There can be important differences between the submitted version and the official published version of record.

People interested in the research are advised to contact the author for the final version of the publication, or visit the DOI to the publisher's website.

- The final author version and the galley proof are versions of the publication after peer review.

- The final published version features the final layout of the paper including the volume, issue and page numbers.

Link to publication

\footnotetext{
General rights rights.

- You may freely distribute the URL identifying the publication in the public portal. please follow below link for the End User Agreement:

www.umlib.nl/taverne-license

Take down policy

If you believe that this document breaches copyright please contact us at:

repository@maastrichtuniversity.nl

providing details and we will investigate your claim.
}

Copyright and moral rights for the publications made accessible in the public portal are retained by the authors and/or other copyright owners and it is a condition of accessing publications that users recognise and abide by the legal requirements associated with these

- Users may download and print one copy of any publication from the public portal for the purpose of private study or research.

- You may not further distribute the material or use it for any profit-making activity or commercial gain

If the publication is distributed under the terms of Article $25 \mathrm{fa}$ of the Dutch Copyright Act, indicated by the "Taverne" license above, 
De maakbare behoefte:

naar een filosofie van duurzame ontwikkeling 


\section{ISBN 9789461590206}

Ontwerp en print: Datawyse | Universitaire Pers Maastricht

Alle rechten voorbehouden. Niets uit deze uitgave mag worden verveelvoudigd, opgeslagen in een geautomatiseerd gegevensbestand of openbaar gemaakt worden, zonder voorafgaande schriftelijke toestemming van de auteur of uitgever. 


\title{
De maakbare behoefte: naar een filosofie van duurzame ontwikkeling
}

\author{
Inaugurele rede in verkorte vorm uitgesproken \\ op 12 november 2010 \\ bij de aanvaarding van het ambt van bijzonder hoogleraar \\ aan de Universiteit Maastricht
}

Harro van Lente

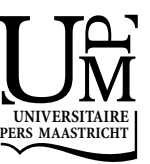


De makbare behoefte: naar een filosofie van duurzame ontwikkeling 
Mijnheer de rector, geachte aanwezigen,

Gisteren, elf november was de dag van de duurzaamheid. Het was ook de dag voor respect en de internationale dag van de wetenschap. Op dezelfde dag, maar dat hoef ik hier in Maastricht niet te melden, werden de eerste vergaderingen van de Raden van Elf gehouden, ter voorbereiding op het komende carnaval. Op dit moment staan wij dus in dit mengsel: duurzaamheid, respect, wetenschap, carnaval.

Twaalf november is nog niet ingelijfd. Vandaag is wel de dag van twee oraties die zich buigen over duurzame ontwikkeling. Dat duurzaamheid tegenwoordig in de belangstelling ligt, is duidelijk. Elk zichzelf respecterend bedrijf of organisatie zal iets met duurzaamheid doen. Dagelijks wordt de krantenlezer geïnformeerd over duurzame energie, duurzaam bouwen, duurzaam ondernemen, duurzaam beleggen en duurzaam bankieren, dit alles na te lezen in duurzaamheidverslagen. Er zijn pogingen om duurzaamheid te meten en om een duurzaam nationaal inkomen vast te stellen.

Wat duurzame ontwikkeling dan is of zou moeten zijn wordt er niet duidelijker op. Velen wijzen erop dat het meer is dan aandacht voor het milieu: het betreft ook de sociale en economische houdbaarheid van ontwikkelingen (Kates, 2001, Ziegler 2010). En hoewel niemand precies weet wat duurzame ontwikkeling is, is iedereen er voor. Het is niet goed voorstelbaar om tegen duurzame ontwikkeling te zijn. Michael McGee (1981) zou de term 'duurzame ontwikkeling', net als de termen 'democratie' of 'vrijheid', opvatten als een ideograaf; dat wil zeggen een term waar je niet tegen kunt zijn, maar die in eerste instantie leeg is en ingevuld kan worden op vele verschillende, zo nodig strategische wijzen. Net als 'vrijheid' en 'democratie' heeft het gebruik van de term een morele lading. Je kunt er niet tegen zijn, hoogstens voor of tegen de manier waarop de invulling plaatsvindt. Een ideologie kan dan opgevat worden als een verzameling ideografen in een bepaalde verhouding 
ten opzichte van elkaar. Een belangwekkende lijn van onderzoek, maar een andere dan ik ga volgen.

De meest bekende formulering van duurzame ontwikkeling is afkomstig uit het rapport van de commissie Brundtland, Our Common Future, uit 1987. De formulering zal misschien aangenaam vertrouwd voorkomen. Toch vraag ik u om er even opnieuw bij stil te staan. Duurzame ontwikkeling is dan een

"development that meets the needs of the present without compromising the ability of future generations to meet their own needs." (43)

Duurzame ontwikkeling wordt hier neergezet als een maatschappelijk ontwikkeling in brede zin, dus inclusief economische, technologische, politieke en culturele aspecten waarbij de behoeften van het heden worden vervuld zonder het vermogen te schaden van toekomstige generaties om in hun eigen behoeften te voorzien.

Als we nu eens van deze invulling uitgaan kom ik tot een observatie. Het merendeel van studies van duurzaamheid gaat over hulpbronnen en de middelen om deze op verstandige en eerlijke wijze aan te wenden: hoe deze op zo'n wijze te benutten dat er van duurzaamheid gesproken kan worden? Het ijkpunt is dan de bestaande situatie; alles dat efficiënter of eerlijker scoort is dan duurzamer. Een horloge met een zonnecel is dan duurzamer dan een horloge met een batterijtje. Een auto met gereduceerd brandstofverbruik is duurzamer dan de auto met hetzelfde brandstofverbruik als voorheen. De breedte aan studies is overigens indrukwekkend, van energiebesparing tot nieuwe landbouwmethoden, van nieuwe logistieke ketens tot aan transitiedenken (dat deels zijn oorsprong in Maastricht heeft, bij mijn collega's van ICIS). De aandacht richt zich op efficiëntere en rechtvaardiger systemen voor maatschappelijke sectoren als vervoer, landbouw of gezondheidszorg. 
Wat veel minder aandacht krijgt is het andere onderdeel van de definitie: de behoeften. Want wat zijn de 'needs of future generations'? Hoe kunnen we daar ooit achter komen? Sterker nog, wat moeten we zien als de 'needs of the present'. Strikt genomen, als we niet weten wat behoeften zijn, kunnen we ook niet weten wat duurzame ontwikkeling is en er ook geen grip op krijgen. Wat zijn dan die behoeften?

\section{het vaststellen van behoeften}

Tien jaar geleden had ik geen behoefte aan een mobiele telefoon, nu heb ik er behoefte aan. Ik wil bereikbaar zijn voor mijn zoon, met mijn dochter kunnen sms-en en mijn vrouw kunnen terugvinden in een drukke stad. Studenten vragen met oprechte belangstelling hoe mijn generatie het klaarspeelde om zonder mobiele telefoon te gaan stappen. Hoe weet je dan in welk café iedereen is? Hoe weet je dat ze al van huis zijn vertrokken? En wat als sommigen besloten hebben ergens anders heen te gaan? Zonder mobieltje stappen? Het kost geestelijk werk om je zo'n avond voor te stellen en de uitkomst is waarschijnlijk zo ingewikkeld dat je er bij voorbaat maar vanaf zou zien.

Dat het lastig is te bepalen wat nu een echte behoefte is, is ook te zien bij zoiets fundamenteels als water. Onze menselijke conditie maakt ons afhankelijk van water, dat staat buiten kijf. Maar hoe groot is onze behoefte aan water dan? Tegenwoordig gebruiken we in Nederland zo'n 250 liter per persoon per dag, om te drinken, om te wassen, om ons voedsel te bereiden. Dat is ooit anders geweest.

In een fraaie studie heeft de Parijse historicus Frédéric Graber (2007) onderzocht hoe de beslissingen over de watervoorziening aan het einde van de $18^{\mathrm{e}}$ en het begin van de $19^{\mathrm{e}}$ eeuw in Parijs tot stand zijn gekomen. Zijn studie laat zien dat waterbehoefte een politieke keus is. Sinds het eind van de $18^{\mathrm{e}}$ eeuw zijn er in een periode van een halve eeuw verschillende pogingen om Parijs van meer water te voorzien. De 
De makbare behoefte: naar een filosofie van duurzame ontwikkeling

eerste studies veronderstelden een dreigend tekort aan water in Parijs, berekend op basis van publiek beschikbare waterbronnen. Dat waren er inderdaad niet veel, maar hoeveel water hebben de inwoners van Parijs dan nodig? Graber laat zien dat het vooral de ingenieurs en ondernemers zijn die de autoriteiten van een tekort aan water proberen te overtuigen. Antoine Deparcieux (1703-1768), een lid van de Académie des Sciences, stelde voor om de rivier de Yvette te verleggen zodat deze ook Parijs zou bereiken. In 1762 stelde hij de benodigde hoeveelheid water op 20 liter per persoon per dag op basis van een gemiddelde, 'misschien wat te veel voor de gewone inwoner, misschien te weinig voor de grote huizen'. Door deze behoefte te veronderstellen kon hij laten zien dat de dagelijkse toevoer van water onvoldoende was. Hij maakt in zijn berekening gebruik van de beroemde Encyclopédie, ou Dictionnaire raisonné des sciences, des artes et des métiers uit 1753 van Jaucourt, waarin wordt berekend dat het via het dak opgevangen regenwater voor een huis met 25 inwoners ongeveer 7,5 liter water per persoon per dag is, 'meer dan genoeg voor al het dagelijks gebruik'. Het verschil is dat Deparcieux andere plannen had met de waterdragers, een belangrijke traditionele schakel in het systeem. Traditioneel liepen waterdragers rond, met twee emmers van elk 15 liter water waarvan ze de inhoud in hun rondes verkochten. Deze emmers waren soms de belangrijkste bronnen van water voor de inwoners van Parijs, maar in de nieuwe plannen pasten zij niet meer. De voorstellen van Deparcieux en andere ingenieurs hadden volgens Graber dan ook een politieke betekenis: zij wilden de rol van de waterdragers minimaliseren en de watertoevoer tot een beheers- en berekenbaar systeem omvormen.

Het project om de rivier de Yvette om te leiden is nooit van start gegaan. Toch bleven er fantasieën bestaan over een betere watervoorziening. De volgende in de rij was François Bralle (1750-1831), een civiel ingenieur die na de Revolutie een belangrijke positie had in het Parijse waterbeheer. In 1799 kreeg hij de vraag van de autoriteiten voorgelegd hoeveel water Parijs nodig had en het was duidelijk dat de overheid het antwoord zou gebruiken in de uit te zetten plannen. Bralle vond het 
echter een te ingewikkelde vraag en speelde deze expliciet terug aan de autoriteiten: de staat dient te bepalen wat de grens is tussen verkwisting en benutting. Zijn argumentatie was helder: de wetenschapper kan slechts bepalen wat de stand van zaken is, maar de beslissing over toekomstig gebruik van water is een politieke. Behoeften, zo was zijn betoog, zijn geen meetbare verschijnselen die objectief vastgesteld kunnen worden; ze hangen samen met intenties, keuzes, idealen en verlangens. Toch wilde hij niet een spelbreker zijn en ging aan het rekenen. De 20 liter van Deparcieux was een mooi begin, maar hield onvoldoende rekening met het feit dat indien er water in overvloed zou zijn, het verbruik zou toenemen. Hij ging daarom maar uit van een berekening met de grootst denkbare hoeveelheid toepassingen, inclusief wasplaatsen, badhuizen en fonteinen. Hij kwam uiteindelijk uit op een schatting van meer dan 100 liter water per persoon per dag. En dáárvoor was een andere rivieromlegging nodig: niet de Yvette, maar de rivier de Ourcq.

De volgende ingenieur in het rijtje, Louis Bruyère (1758-1831) deed opnieuw berekeningen aan de plannen, maar besloot dat een andere rivier, de Beuvronne, nog geschikter was. De schattingen voor de waterbehoefte van Bralle verwierp hij, sterker nog, hij verwierp elke speculatie over toekomstig gebruik. Wetenschappers en ingenieurs mogen alleen uitgaan van de werkelijkheid en dienen als schild te fungeren voor de overheid om deze te beschermen tegen wilde speculaties en beloften die vooral de belangen van betrokken ondernemers dienen. Hij bekritiseerde ook de schatting van 20 liter per persoon per dag dat al lange tijd circuleerde en zette zich aan de taak om het werkelijke gebruik te bepalen. Zijn conclusie was: "Het is een feit, en iedereen kan het controleren, dat een familie van 10 individuen gemiddeld [...] slechts 69 liter per dag gebruikt". Dus geen 100 liter, maar 7 liter water per persoon per dag is de behoefte.

Ook de omlegging van de rivier de Beuvronne is er niet van gekomen. De opvolgers vonden de uitgangspunten van Bruyère ondeugdelijk en 
gingen juist uit van de grootst mogelijke toevoer van water. Parijs zou nooit water genoeg hebben, was hun redenering; altijd zou er wel een nuttige of plezierige bestemming gevonden worden. Ingenieurs moeten niet bepalen wat de behoefte is, zij moeten zich houden aan wat beschikbaar is. Wetenschappers en ingenieurs horen zich te beperken tot dat wat te meten en te berekenen is - hierin waren zij het wel eens met François Bralle. En wat te meten is, is het aanbod van water, niet het toekomstig gebruik. Zo laat deze episode in de geschiedenis van Parijs zien dat zoiets basaals als de bepaling van de behoefte aan water een hachelijke zaak is. De studie laat ook zien dat de vaststelling van 'behoefte' onderdeel was van het spel tussen opdrachtgevers, technici en ondernemers waarin ingenieurs kans zagen zichzelf als professie te vestigen.

Een tweede voorbeeld betreft een evenzeer basale behoefte: behuizing. Huizenbezitters en mensen op woningjacht kennen het verschijnsel van de maakbare woonbehoefte en begrijpen als de makelaar omineus verklaart dat een woning 'aangepast moet worden aan de eisen van deze tijd'. Ik put hier uit een studie van de Noorse onderzoekster Siri Ytrehus, die heeft onderzocht hoe in het naoorlogse Noorwegen de behoefte is aan behuizing is vastgesteld (Ytrehus, 2000). Wat is een normale woonbehoefte? Zijn er onder- en bovengrenzen aan deze behoefte? Hoe kan de overheid hier verstandig in opereren?

Ook hier zien we dat de vraag wat gelegitimeerde behoeften zijn uitbesteed is aan een professie. Zoals de vaststelling van de behoefte aan water in het $19^{\mathrm{e}}$ Parijs is gedelegeerd aan de opkomende professie van ingenieurs, is het vraagstuk van benodigde woonruimte in Noorwegen gedelegeerd aan architecten en woningcorporaties. Ytrehus onderscheidt in de vaststelling van woonbehoefte drie stromingen. De eerste na de oorlog is een rationalistische en reductionistische stroming die uitgaat van de fysieke aspecten: wat is de kwaliteit en de grootte van de woonruimte? De woonsituatie wordt met 'objectieve' en 'wetenschappelijke' gronden ingedeeld in de categorieën 'voldoende', 'onvoldoende' of 'buitensporig'. Dit objectieve perspectief, met zijn aandacht 
voor de normering van woonbehoefte, is geheel in lijn met het na de tweede wereldoorlog populair geworden functionalisme in de architectuur. De achterliggende idee is dat de mens in principe rationeel handelt, mits voorzien van gericht onderwijs en de juiste opvoeding. Met behulp van standaarden kan dan afgeleid worden of en hoe aan de woonbehoefte is voldaan. Hierbij is niet alleen de woonoppervlakte van belang, maar ook het woongedrag. "A room of 20 square meters filled up with unpractical furniture and unnecessary things is not more hygienic and spacious than a room of 10 square meters with few, but practically and correctly organised furniture" [Reiersen and Thue 1996, 46, geciteerd in Ytrehus 2000, 167]

In laboratoriumexperimenten werden testpersonen gevolgd om rationeel woongedrag te vast te stellen en, op basis daarvan, standaarden. Ytrehus noteert een samenhang van deze benadering met de destijds in Noorwegen vigerende ideeën van modernisering en 'social engineering'. Noorwegen was trouwens geen uitzondering; ook in Nederland en elders is deze stroming goed herkenbaar (Albert de la Bruhèze en Oldenziel, 2009).

Een tweede stroming die in de jaren tachtig van de vorige eeuw dominant is geworden in de vaststelling van woonbehoefte, is het marktperspectief. Hier wordt niet uitgegaan van het bestaan van objectieve behoeften die in laboratoria vast te stellen zijn, maar worden behoeften opgevat als 'preferenties' die slechts zichtbaar en relevant zijn voor zover ze getoond worden in economische beslissingen. Het vaststellen van vaste standaarden van woonbehoefte is in dit perspectief niet alleen onmogelijk maar ook onwenselijk, want paternalistisch. Mensen kiezen zelf wel en wat zij kiezen is kennelijk hun behoefte. Meer hoef je niet te weten, meer mag je niet weten.

In het marktperspectief zijn er geen objectief vast te stellen behoeften, alleen subjectieve preferenties. Het waken over 'basic needs' dat in de eerste stroming zo centraal stond is overbodig geworden omdat vol- 
gens de principes van de markt de uitkomsten zich vanzelf schikken naar de behoefte. Het lijkt een hele opluchting om de experimenten en standaarden achter ons te kunnen laten, maar vanuit vele kanten zijn inmiddels de beperkingen van het liberale marktperspectief onder vuur genomen, onder andere door Hans Achterhuis (2010) in De utopie van de vrije markt. De aanname van een 'perfecte markt' met volledig geïnformeerde deelnemers is niet realistisch. De beslissingen van de deelnemers zullen dan ook veel willekeuriger zijn en dat zet de aanname van goede uitkomsten onder druk. Daarnaast zullen preferenties zullen vooral ook de sociale posities weerspiegelen. Reeds in 1984 wees Nobelprijswinnaar Amyarta Sen erop dat individuele preferenties meer verbonden zijn met sociale en culturele posities dan met de individuele situatie (Sen 1984: 13). Het marktperspectief heeft dus de neiging om de bestaande verdeling van woningen als afdoende te sanctioneren. Mensen wonen er, dus is het hun keuze om daar te wonen, dus is het hun preferentie, dus is het adequaat.

In Noorwegen zijn er vanaf de jaren 80 pogingen geweest om de twee benaderingen te combineren. Dat stuit echter op een theoretische paradox: het is lastig om behoeften zowel als subjectief als objectief te zien. De marktbenadering neemt behoeften als individuele preferentie en kan dus geen uitspraak doen over de vraag of de woning 'te groot' of 'te klein' is. De objectieve benadering wil echter toezien op een eerlijke verdeling van woonruimte op basis van de woonbehoefte.

De derde relativistische stroming, tenslotte, ziet behoeften als sociaal geconstrueerd en verschillend in tijd en ruimte. Zo zal de standaard voor armoede, bijvoorbeeld, verschuiven bij een algemene vooruitgang. Of, zoals Peter Townsend, in zijn boek Poverty in the United Kingdom (1979: 17) het formuleerde: "The necessities of life are not fixed. They are continuously being adapted and augmented as changes take place in a society and in its products." Behoeften zijn variabel, afhankelijk van tijd, plaats, klimaat of sociale omstandigheden. In de studie van armoede speelt de relativistische traditie een grote rol. Townsend geeft 
het voorbeeld van televisie: of dat een behoefte is, is afhankelijk van hoeveel anderen een televisie hebben. Het criterium van armoede is dan 'deprivatie'. Armoede en behoeftigheid worden dan een relationele categorie: "People can be taken to be deprived if they lack the type of diet, clothing, housing, environmental, working and social conditions, activities and facilities which are customary, or at least widely encouraged or approved, in the societies to which they belong" (Townsend 1979: 413 geciteerd in Ytrihus 2000). In de huidige Noorse situatie zien we een mengsel van de drie stromingen.

In deze studies van de Parijse watervoorziening rond 1800 en de naoorlogse Noorse woonpolitiek zien we verschillende bepalingen van behoefte de revue passeren. Er zijn opvattingen die een behoeft als iets objectief, iets subjectiefs of iets relationeels zien. En deze opvattingen impliceren verschillende ideeën over wat een goede politiek zou zijn. Tevens laten deze twee studies zien dat het bepalen van een behoefte geen abstracte bezigheid is, maar maatschappelijk gelokaliseerd en georganiseerd, in professies of andere institutionele vormen.

\section{behoefte en innovatie}

De voorbeelden van water en wonen laten ook zien dat behoeften veranderen met de tijd. De vraag is hoe dat komt. Innovatie speelt in ieder geval een belangrijke rol. Uit de innovatieliteratuur leren we dat succesvolle innovatoren niet zozeer een nieuwe vinding tot stand brengen maar vooral ook een nieuwe markt. Een mooi voorbeeld is George Eastman die aan het eind van de $19^{\mathrm{e}}$ eeuw, in de tijd dat fotografie een specialistische bezigheid was, die chemische kennis vereiste over lichtgevoelige zilveremulsies, transformeerde naar een bezigheid voor de massa (Utterback 1993). Zijn slogan "you press the button, we do the rest" heeft nog steeds een magische klank. Zijn inspanningen om fotograferen een massa-activiteit te maken betroffen zowel technische aanpassingen - zoals het prepareren van celluloid als drager van emul- 
sie - als het zorgvuldig positioneren van de nieuwe producten in de collectieve verbeelding. Fotograferen hoorde bij de taak van een goede ouder, of van een goede gastheer. "Every vacation needs a Kodak", of sterker nog, zoals een slogan uit 1902 het stelde: "A vacation without a Kodak is a vacation wasted".

Ook andere succesvolle innovatoren hebben hun roem vooral te danken aan de gezamenlijke ontwikkeling van product en markt. Denk aan Henri Ford, die de auto voor de massa ontwikkelde, of Bill Gates die in de jaren tachtig handelde vanuit de visie dat elke bureau op deze wereld een PC zou hebben. Met zijn software natuurlijk, hoor je er dan zuur bij te zeggen. Eén van de bekendste management onderzoekers Peter Drucker, formuleerde het ooit als volgt: "There is one valid definition of business purpose: to create a customer" (Drucker 1954, 37).

Een klant maken is makkelijker gezegd dan gedaan. De innovatieliteratuur leert ons ook dat het gebruik van een vinding niet geheel in de handen is van de ontwerper (Latour 1987). Een duidelijk voorbeeld dat ik graag aan mijn studenten voorhoud is ontleend aan het werk van de Amerikaanse historicus George Basalla. In zijn Evolution of Technology (1988) bespreekt hij de fonograaf van Thomas Edison, iets wat we nu herkennen als de voorloper van de grammofoonspeler. Thomas Edison was de held van het modernistische Amerika, een voorbeeld van de American Dream en nog steeds wereldrecordhouder met meer dan 1000 octrooien op zijn naam. Een hardwerkende, serieuze man. Bij de presentatie van zijn fonograaf in 1877 , die geluidsgolven kon registreren in was en later weer weergeven, kreeg hij lof maar ook vragen. Interessant, zonder meer, opmerkelijk ook, maar wat moet je ermee? Een jaar later publiceerde hij een lijst van tien gesuggereerde toepassingen van zijn fonograaf. Achtereenvolgens waren dat: dictaat opnemen zonder stenograaf; sprekende boeken voor blinden; cursussen spreken in het openbaar; weergave van muziek; belangrijke familiebesprekingen vastleggen; de laatste woorden van stervenden vereeuwigen; nieuwe soorten geluiden; sprekende klokken; uitspraak van 
vreemde talen; het vastleggen van telefoongesprekken. Het weergeven van muziek was dus maar één van suggesties en Thomas Edison, een serieus hardwerkende man, kon het moeilijk verdragen dat zijn uitvingen gebruikt, of misbruikt, zouden worden voor nutteloze, frivole zaken. Zijn medewerkers meenden in de jaren na de introductie echter dat juist deze toepassing, muziek, meer potentie had en zetten door, tegen de zin van Edison.

In innovatiestudies is de creatieve rol van gebruikers een belangrijk thema. Zij bepalen niet alleen óf een innovatie gaat slagen, maar ook wát de innovatie is (Oudshoorn en Pinch 2003). Ontwikkelaars pogen daar wel greep op te krijgen, maar dat lukt slechts in beperkte mate. Een centrale boodschap uit de innovatieliteratuur is de vaststelling dat bij de introductie van nieuwe vindingen een leerproces nodig is. De Maastrichtse hoogleraar Wiebe Bijker is wereldberoemd geworden met zijn studie naar het leerproces bij de fiets (Bijker 1995). Hij benadrukt dat interpretaties van een artefact flexibel zijn en dat het geruime tijd kan duren - in het geval van de fiets een kwart eeuw - voordat er een min of meer gezamenlijke interpretatie ontstaat van het nieuwe ding. Strikt genomen duurde 'de uitvinding' van de fiets dus een kwart eeuw. Gedurende deze tijd veranderen niet alleen de interpretaties, maar ook de verschillende ontwerpen en omstandigheden waarin ze gebruikt werden. Pas na een kwart eeuw zien we de buitengewone diversiteit in ontwerpen afnemen en kunnen we spreken van een 'standaardfiets'. Van een onbegrijpelijk apparaat is de fiets een onmisbaar onderdeel geworden van het leven, in ieder geval in Nederland. Ontwikkelaars en gebruikers hebben samen de uiteindelijke vorm bepaalt van de fiets en de behoefte aan fietsen.

Hetzelfde patroon doet zich gelden voor andere technologieën die we nu als vanzelfsprekend zien (Utterback 1993). Terugkijkend is het ontstaan van nieuwe behoeften daarin goed te traceren. De introductie van de Personal Computer ligt de ouderen onder ons nog goed in het geheugen. Het kostte in de jaren '70 en ' 80 verbeeldingskracht en ex- 
perimenten om tot een definitie te komen van wat een computer is en wat je ermee kunt doen. Beroemd zijn de inschattingen van Thomas Watson, directeur van IBM, in 1943: "I think there is a world market for maybe 5 computers". Ik herinner mij ook het dedain waarmee het eerste gebruik van PCs door secretaresses werd besproken. Een PC als typemachine gebruiken is alsof je met een Ferrari boodschappen doet! En inmiddels doet iedereen met een Ferrari boodschappen, al zullen de mopperaars opmerkend dat de Ferrari's zo belast zijn met software dat de winst in termen van pure snelheid erg tegenvalt.

We kunnen ook behoeften in wording zien. Neem de iPad. Ook hier, in het begin, verwarring en onbepaaldheid: wat is het, wat kun je ermee en waarom zou je dat doen? Het leerproces is in volle gang; gretig en nieuwsgierig wordt in allerlei rubrieken en websites besproken wat dit apparaat nu toch moet zijn. En vooral ook: welke markt gaat het openen, welke gevestigde markten gaat het bedreigen? Interessant is hier de opgewonden en bereidwillige overtuiging dat het iets gaat verschuiven, zoals dat is gebeurd met de iPod, de iPhone en de iDontknow. De techniekhistoricus David Nye (1996) duidde de combinatie van verrukking, ontzag en vrees als 'the technological sublime'. Het weekblad The Economist vatte deze combinatie van ontzag en willigheid samen door de regisseur van Apple, Steve Jobs, op de voorpagina af te beelden als een heilige, met de iPad in zijn handen. Het bijschrift was: 'the book of Jobs'. Wat er precies gaat gebeuren weten we niet, maar dat er wonderen op komst zijn staat buiten kijf. Wélke behoefte het gaat maken en vervullen weten we niet (ook Steve Jobs niet), maar wel dát er nieuwe behoeften gaan komen. Uiteraard is het niet gezegd dat het beslist een succes gaat worden, dat is immers altijd ongewis. Maar de bereidwilligheid om het als nieuwe behoefte te aanvaarden, hoe oningevuld de behoefte ook is, is opmerkelijk.

We zien nu dat behoeften niet zozeer aan het begin van een technische ontwikkelingen staan, maar aan het eind, als nevenuitkomst van hetzelfde traject. Het standaardbeeld van de techniek als bondgenoot van 
de mens in zijn strijd met de vijandige natuur gaat al lang niet meer op. In mijn onderzoek naar de rol van verwachtingen heb ik dat ook aangegeven: moderne technologische ontwikkelingen beginnen niet zozeer met een geconstateerd probleem of behoefte, maar met een belofte die vervolgens wordt omgezet in vereisten (Van Lente en Rip 1998, Van Lente 2010). Elementen van de dynamiek van behoeftevorming zijn het bedrijf dat wil overleven en innovatie als nuttige strategie ziet, de nieuwsgierigheid en gretigheid van het leerproces van gebruikers, de nieuwe vormen van gebruik die langzamerhand onderdeel worden van het dagelijks leven. In de innovatieliteratuur wordt deze laatste stap de 'domesticatie' van technologie genoemd (Silverstone 1992, Williams ea 2004). Het nieuwe wilde monster wordt getemd en krijgt een plaats in een manier van leven, met alle vooronderstellingen, gebruiken en regels die daarbij horen. De manier van leven verandert daardoor ook enigszins.

Als we deze gedeeltelijke reconstructies van het ontstaan van behoeften samennemen komen we tot het volgende voorlopige totaalbeeld. Producten en diensten worden ontwikkeld in een omgeving van concurrentie, innovatieraces en innovatoren die hierin mogelijkheden zien. Zij worden in hun pogingen gesteund door de cultureel verankerde overtuiging dat er altijd een volgende generatie van een product of technologisch systeem zal zijn. Er wordt attent gespeurd naar tekenen van de volgende stap, de volgende generatie en de inzet van concurrenten wordt nauwlettend bijgehouden. Door strategische spelen en door self-fulling prophecies heeft moderne technologie-ontwikkeling een eigen dynamiek (Van Lente 2000, Van Lente 2010). Elk bedrijf weet dat het moet innoveren om te overleven. Het is een platitude - een bedrijf moet innoveren om te overleven - en het is buitengewoon verbazingwekkend.

De vindingen, de ideeën, de opties waarmee bedrijven hun geluk beproeven zijn in eerste instantie nog onbepaald, en worden onderdeel van een leerproces dat bepaalt wat zoiets als een fiets is, een mobiele 
telefoon, een auto, een iPad. Met belangstelling en gretigheid en soms wat gemopper wordt geëxperimenteerd en geleerd. En de stamvader van de innovatieliteratuur, Everett Rogers, kan ons netjes vertellen dat de gebruikers en potentiële gebruikers uit groepen bestaan: er zijn de 'early adopters' die gefascineerd de grens volgen, de grote middengroep die niet vooruit wil lopen en niet wil achterblijven, mensen als $u$ en ik dus, en de achterblijvers, die lang zullen volhouden dat ze zoiets als een fiets, mobiele telefoon, auto of iPad niet nodig hebben. Tenslotte zullen ook zij capituleren, of preciezer gezegd: ontdekken dat ze een behoefte hebben. De wereld waarin zij leven verandert immers en gaat zich vormen rond de mogelijkheden van fiets, mobiele telefoon, auto of iPad. 'Wat onhandig dat we je niet mobiel kunnen bereiken.' 'Wat elitair om geen televisie te willen.' 'Als u ons niet onze website kunt raadplegen weten we het niet meer'. Een van de krachten die hier spelen wordt in de evolutionaire economie ook wel omschreven als netwerkeffect: de meerwaarde van een product neemt toe naarmate het meer verspreid is in de omgeving (David 1985, Arthur 1988). Het netwerkeffect zorgt er ook voor dat de straf om niet mee te doen evenredig toeneemt.

De wereld voegt zich dus rond een nieuwe vinding en is daarmee anders geworden. De achterblijvers zullen merken dat hun afwijzing van wat een in hun ogen een onnodige vernieuwing was, een zonderling karakter gaat krijgen, een wereldvreemd karakter, vreemd in de veranderde wereld. Ook de grote middengroep zal af en toe opkijken en merken dat wat eens een interessante of irritante nieuwigheid was, een normaal element is geworden, noodzakelijk om te blijven functioneren. Het is, met andere woorden, een behoefte geworden: iets waarvan we hinder ondervinden, stress of ongemak als het weggenomen zou worden. De vernieuwing kan zelfs een recht worden, zoals het hebben van internettoegang soms als recht geponeerd wordt. Denk aan de discussies over de digital divide: de categorie armen omvat nu ook degene die niet aangesloten zijn op het wereldwijde web van rondgepompte informatie (Wyatt e.a. 2005). Het nieuwe element is van 
een onbepaalde noviteit getransformeerd in een vaste bewoner, een behoefte en soms uiteindelijk als recht. In deze aldus veranderde wereld zullen de volgende vernieuwingen weer als veelbelovend beoordeeld worden, en weer de cyclus van innoveren, experimenteren, leren, domesticeren, standaardiseren en socialiseren doorgaan. Enzovoorts. Het leven is onuitsprekelijk vermoeiend, zegt Prediker (1:8).

Op dit moment zult u zich misschien twee zaken afvragen. Ten eerste, het is toch niet zo dat alle geponeerde vernieuwingen eindigen als een ingebed product. Nee, inderdaad velen zullen het niet halen. De schattingen lopen uiteen, maar hooguit $10 \%$ van de veelbelovende ideeën in een laboratorium of een R\&D afdeling zullen het verder schoppen dan veelbelovend idee. Het is immers een proces van trial en error, een evolutionaire afvalrace, op alle fronten en in alle stadia - daar helpt geen moedertjelief aan. Maar dat maakt voor dit verhaal niet uit, het scheppingsverhaal van behoeften.

Ten tweede kunt $\mathrm{u}$ zich afvragen: wat is het probleem? Het is misschien opmerkelijk, misschien zelfs onuitsprekelijk vermoeiend, maar het levert per saldo toch ook veel moois op. Ook daarin heeft u gelijk, het levert veel moois op. Ik zie echter twee problemen. Het eerste probleem betreft het democratisch gehalte. Ik heb nu een mobiele telefoon, ik heb daar behoefte aan en twintig jaar geleden was dat niet zo. In die twintig jaar ben ik nooit geconsulteerd of ik deze behoefte zou willen hebben. Ik ben ook nooit geconsulteerd over mijn behoefte aan vakanties naar exotische oorden waar ik ook absoluut foto's van wil maken. En u ook niet. En aangezien een behoefte toch een intiem en pregnant onderdeel is van het persoonlijke leven zou je dit een democratisch tekort kunnen noemen, dat des te dringender wordt indien je beseft dat op dit moment de behoeften die ik over twintig jaar zal hebben reeds in de maak zijn. Ik zou daar wel inspraak in willen. Baas over eigen behoefte!

Het tweede probleem betreft duurzame ontwikkeling. Want als duurzaamheid alles te maken heeft met het vervullen van behoeften, van 
ons en volgende generaties, dan zitten we hier met een lastig gegeven: de aldus ontstane behoeften gaan niet zomaar weg. Mensen vragen hun mobiel uit te zetten lukt meestal wel, maar verzoeken om hun mobiel nooit meer te gebruiken is een brug te ver. Eén autorit overslaan kan dan nog, maar geheel afzien van autobezit is teveel gevraagd. Bereikbaarheid en mobiliteit is nog net geen recht maar het zit er dicht tegenaan. De centrale vraag voor een filosofie van duurzame ontwikkeling is wat mij betreft dan ook: welke behoeften kunnen we ons veroorloven?

\section{behoefte en begeerte}

Op dit punt op de zoektocht naar de maakbare behoefte is het nodig een diepere duik nemen in het idee behoefte zelf. Wanneer spreken we over een behoefte? Wat zegt een behoefte over ons zelfbegrip, individueel en collectief?

Laten we eerst even stilstaan bij de meest geciteerde auteur op het gebied van behoefte. Abraham Maslow maakte in de jaren '50 naam met het onderscheid van vijf soorten behoeften en hun rangschikking in een hiërarchisch verband. De veronderstelling is dat vervulling van de 'hogere' behoeften slechts mogelijk is wanneer de lagere behoeften zijn vervuld. De hogere staan op het fundament van de lagere, vandaar dat Maslow spreekt over een piramide. Onderaan de piramide vinden we lichamelijke behoeften, en in dat rijtje horen ademen, eten, drinken, seksualiteit. Dan volgt de behoefte aan zekerheid, aan lichamelijke integriteit en de behoefte om ergens thuis te horen, geaccepteerd te worden, zelfvertrouwen te hebben. Als aan deze behoeften is voldaan zal een volgende laag zich aandienen: het begrijpen en ontdekken. We zijn immers niet alleen een lichamelijk en sociaal wezen, maar ook een denkend en appreciërend wezen, aldus Maslow. Ook de esthetische behoeften aan schoonheid en orde vallen in deze categorie. De hoogste behoefte - en Maslow geeft aan dat deze niet bij iedereen zich zal aan- 
dienen - is de behoefte aan persoonlijke groei, aan zelfverwerkelijking. Om een heel mens te zijn volstaat het niet om een gerespecteerd en gezond deelnemer van een samenleving te zijn, er is ook een noodzaak tot vervulling. Merk op dat in het systeem de lagere behoeften uitgaan van een gebrek, dat aangevuld of voorkomen moet worden, en de hogere behoeften uitgaan van een surplus, van groei.

De piramide van Maslow is na een halve eeuw nog steeds een mijlpaal en ankerpunt. In het marketingonderzoek, bijvoorbeeld - het is vele malen groter dan het filosofisch en innovatieonderzoek bij elkaar - is de indeling van Maslow nog steeds een stevige basis voor klantsegmentatie en marktstrategieën. Maslowing heet dat. Of zoals een standaardwerk over marketing toelicht: "Consumer motivation represents the drive to satisfy both physiological and psychological needs through product purchase and consumption." (Blackwell e.a. 2001, 255). Zoals gezinnen hun jaarlijkse uitje beleven bij de piramide van Austerlitz, hebben marketingonderzoekers een dagelijks uitje bij de piramide van Maslow.

Toch is ook veel kritiek op de behoeftenpiramide. Er wordt op gewezen dat de hogere behoeften, bijvoorbeeld die van zelfverwerkelijking, de lagere behoeften kunnen vervangen. Mensen kunnen het klooster ingaan en afzien van partner en gezin of zich wijden aan een oratie en afzien van simpele genoegens. Bergbeklimmers zijn bereid om hun veiligheid in gevaar te brengen voor een, letterlijk, hoger doel. In dit verband is het interessant om zien dat Abraham Maslow in zijn latere jaren een pleitbezorger werd van de transpersoonlijke psychologie. Hij noemde dit de noodzakelijke vierde invalshoek van de psychologie, naast de (i) psychoanalyse die zich vooral bekommert om pathologie, (ii) het behaviorisme met zijn nadruk op patronen en regels en (iii) de humanistische psychologie die zich richt op zelfverwerkelijking. Maslow behoorde zelf, begin jaren '60 samen met Carl Rogers en Erich Fromm tot de grondleggers van de humanistische psychologie die zicht richt op de 'hoogste' behoefte, zelfverwerkelijking, maar later pleitte hij voor 
De makbare behoefte: naar een filosofie van duurzame ontwikkeling

een transpersoonlijke psychologie om recht te doen aan ervaringen voorbij het persoonlijke, aan ervaringen van eenheid.

Een tweede werk dat invloedrijk is geworden rond het thema behoefte is A Theory of Human Need van Len Doyal en lan Gough (1991), beiden uit Groot-Brittannië. Zij willen een middenweg bewandelen tussen essentialisme en relativisme. Ze erkennen dat behoeften verschillen per plaats en per tijd, en dat behoeften gevormd en bemiddeld worden door de cultuur. Toch menen ze dat het nodig is om een niet-relatief uitgangspunt te hebben om zinvol over behoefte te kunnen denken. In hun normatieve positie stellen zij dat behoeften zijn af te leiden uit twee voorwaarden voor elke beschaving: lichamelijke gezondheid en autonomie. Beiden zijn noodzakelijk voor participatie in een samenleving, ongeacht de cultuur: zonder gezondheid geen deelname en zonder autonomie geen mogelijkheid om keuzen te maken. De ankersteen in hun theorie is het idee van vermijden van 'serious harm': een ernstige bedreiging van de mogelijkheid om maatschappelijk te participeren. Vanuit het vermijden van ernstig letsel leiden Doyal en Gough een reeks 'intermediate needs', 'tussenliggende behoeften' af, zoals voeding en schoon water; afdoende behuizing; een veilige werkomgeving; afdoende gezondheidszorg; een redelijke economische zekerheid; een veilige jeugd en onderwijs.

Belangrijk is om te zien dat deze normatieve invulling van behoeften niet automatisch samenvalt met individuele preferenties. Gough en Doyal benadrukken dat nodig is om behoeften onafhankelijk van subjectieve beleving en preferenties te specificeren. In hun derde hoofdstuk, over de 'grammatica van behoeften', onderscheiden Gough en Doyal twee verschillende wijzen van spreken over behoefte. De meest gebruikelijke, ook in het dagelijks taalgebruik, is om behoefte te zien als een drijfveer, een motiverende kracht om een gebrek op te heffen of een persoonlijk doel te bereiken, zoals we gezien hebben bij Abraham Maslow. Een andere manier om te spreken over behoeften is om ze los te koppelen van motivatie en drijfveren. Behoeften verwijzen dan naar 
doelen met een universele gelding. 'Deze persoon heeft eiwit nodig.' 'Deze familie heeft behoefte aan een betere huisvesting.' Om dit te verhelderen is het volgens Gough en Doyal nodig om een onderscheid tussen behoeften (needs) en wensen (wants) te maken. Terwijl behoeften universele zaken betreffen, zullen wensen particulier zijn en variëren van persoon tot persoon. We horen hier ook de echo van Mahatma Gandhi die ooit verzuchtte dat "de wereld genoeg biedt voor ieders behoefte maar niet voor ieders begeerte."

Indien behoefte in deze tweede, universele, zin wordt opgevat is het mogelijk om een claim over behoefte te bestrijden: ik heb behoefte aan een grote portie frites. Bij een wens of begeerte is dat niet mogelijk: je kunt moeilijk beweren dat iemand geen grote portie frites wil. De oplossing van Gough en Doyal om uit te gaan van het principe van het vermijden van 'serious harm' lijkt een gouden greep, maar is bij nadere beschouwing, zoals ze zelf ook opmerken, toch niet probleemloos. Want ook overeenstemming over wanneer sprake is van 'serious harm' is niet vanzelfsprekend, noch de wijze waarop aan deze behoefte tegemoet gekomen kan worden; denk aan de discussie over de Noorse woonbehoefte. En dan begint het onderscheid tussen 'behoefte' en 'begeerte' weer te verbleken daarmee ook het publieke en betwistbare karakter van behoeften. Of zoals zij zeggen: "This distinction between needs and wants, therefore, seems to be essentially normative: if agreement about values does not exist, there seems to be no further grounds for arbitration."(p.43)

Een filosoof die zich volledig geconcentreerd heeft op een theorie van begeerte, is René Girard. Uitvoerig laat hij aan de hand van allerlei bronnen, zoals antropologische studies en westerse romans, zien dat de begeerte mimetisch is. We apen elkaar na in onze begeerte. Mensen tappen niet uit een eigen bron waaruit hun begeerte opwelt, maar hebben anderen nodig als model voor hun begeerte. Het gekoesterde idee dat we zelf bepalen wat we begeren en dat deze begeerte verbonden is met onze identiteit, noemt Girard een 'romantische leugen'. 
Daartegen over zet hij de 'romaneske waarheid' dat we daarentegen anderen als model volgen, die daarmee tegelijk onze rivaal worden. Dat dit leidt tot spanningen en gewelddadigheden laat zich raden. Je zou kunnen stellen dat de marketing leeft van de romantische leugen op een transparante wijze: we zien iemand met product $X$ en dienen daaruit af te leiden dat wij nu ook product $\mathrm{X}$ begeren. Overigens bedreigt René Girard met zijn theorie ook de kroonjuwelen van het humanisme: het autonome individu dat zichzelf vanuit een eigen originele visie vormgeeft aan zijn leven en verantwoordelijkheid. Veel autonomie en originaliteit zal er doorgaans niet zijn, volgens Girard, maar na-aperij in een romantisch sausje.

De analyses van Girard leiden ook tot een nieuwe visie op het verschijnsel 'schaarste', zoals ook uitgebreid door Hans Achterhuis (1988) is onderzocht in Het rijk van de schaarste. Als het waar is dat onze begeerte mimetisch is, is er vanzelf ook een tekort, want we willen uitgerekend datgene wat onze buurman en buurvrouw ook heeft. In het premoderne tijdperk werden deze verlangens geketend door religie, denk aan het tiende gebod: 'Gij zult niet begeren...' (Exodus 23). De grote ommekeer echter, die de liberale filosofen als Hobbes, Locke en Hume hebben verwoord, is dat de begeerte in de liberale samenleving vrijgegeven wordt en zelfs wordt aangemoedigd als voertuig van maatschappelijke vooruitgang. De markt immers zorgt ervoor dat de optelsom van nagejaagde privé-belangen positief zal zijn. Het menselijk ongeluk wijst niet langer naar een gebrek aan deugdzaamheid (het pre-moderne antwoord) maar naar het tekort aan natuurlijke hulpbronnen. De natuur is de schuldige: zij schiet tekort en daarom worden mensen tegen elkaar opgezet. De oplossing ligt voor de hand: productie om aan alle behoefte te kunnen voldoen. Steeds meer productie, alle hens aan dek.

Naast het grimmige beeld dat Girard schetst van behoefte, als iets dan ten nauwste gekoppeld is aan geweld, heeft ook zijn cultuurhistorische analyse weinig goeds in petto. De vooruitgang zoals we die in de moderne tijd omarmd hebben als veelbelovende mogelijkheid, is in zijn 
ogen niet meer dan een vlucht vooruit om het gegeven van de mimetische begeerte te kunnen bedekken. Dit cultuurpessimisme vindt op vele plekken weerklank, bijvoorbeeld in het werk van de Vlaamse filosoof Etienne Vermeersch (1988) die in de jaren '80 furore maakte met zijn typering van het WTK-bestel: wetenschap, technologie en kapitalisme houden elkaar vast in een onzalige verstrengeling die ooit wel op moet lopen tegen grenzen. Er is zeker grond voor pessimisme, maar toch lijken filosofen als Girard en Vermeersch zich te verkijken op de mogelijkheden van bewustwording en volwassenwording.

In een andere filosofische traditie worden behoeften niet geplaatst in het licht van competitie en geweld, maar in het licht van verbeelding en het goede leven. De Spaanse filosoof Ortega y Gasset inspireerde mij ook eerder in mijn studie van verwachtingen in technische ontwikkeling (Van Lente 1993, 2003). In 1951 verscheen de Nederlandse vertaling, 'Bespiegeling over de techniek' van zijn Meditación de la técnica in 1935 in het Argentijnse dagblad La Nación verscheen. Ortega verzucht hierin dat in het denken over techniek zo'n simplistische visie over behoeften naar voren komt. "De boeken over techniek die ik heb gelezen en die werkelijk allemaal hun geweldig onderwerp onwaardig zijn, beginnen met niet te beseffen dat het begrip 'menselijke behoeften' van het grootste belang is om te verduidelijken wat de techniek is." ( 25). Hij begint bij het begin, bij de meest onmiskenbare behoeften. Waarom beschermen we ons tegen de kou, voeden we ons, drinken we? Het lijken absurde vragen, maar het antwoord is van belang: we kleden en voeden ons omdat we willen leven! Leven is de basisbehoefte, vanwaar al het andere afgeleid wordt. En benadrukt Ortega, dat 'leven' dat we willen is niet zomaar gegeven, dat moeten we eerst zelf uitvinden. Hij verwijst naar antropologische studies die tonen dat instrumenten die van nut zijn voor het fysieke overleven, hand in hand gaan met 'genotmiddelen', met ogenschijnlijk overbodige instrumenten. Zelfs het vuur, de moeder van alle uitvindingen, wordt niet alleen gebruikt om zich te verwarmen, maar vanaf het begin ook voor bedwelming. De geschiedenis van de mensheid laat een eindeloze reeks 
genotmiddelen en 'onnuttige' zaken. Zo is het bijvoorbeeld onduidelijk of de boog het eerst voor muziek of het eerst voor de jacht is gebruikt. De conclusie is dat de menselijke behoefte zowel het nuttige als het overbodige omvat en de grens is niet duidelijk. "Het welzijn en niet het zijn is de fundamentele behoefte van de mens." (23).

Het willen leven als basisbehoefte moeten we dus vooral opvatten als het goed willen leven. Hier ontstaat een nieuwe categorie 'leven' die voor dieren niet beschikbaar is: het leven als een zelfgeschapen verhaal. "Als u nu even doordenkt, zult u zien dat datgene wat u uw leven noemt, niets anders is dan het verlangen om een bepaald levensplan of -programma uit te voeren." (36). "En juist dat uitgevonden leven, uitgedacht zoals men een roman of een toneelstuk uitdenkt, noemt de mens menselijk leven, wel-zijn. (...) Wat? Het menselijke leven zou dus in zijn specifieke dimensie een...fantasiewerk zijn? Zou de mens een soort van romancier van zichzelf zijn, die de fantastische figuur construeert van een persoon met een eigen variabel type van bezigheden en die om die te kunnen verwezenlijken al zijn handelingen verricht (...)?"(32-33).

Dat behoefte verwijst naar het goede leven is een lijn die perspectieven opent. De Amerikaanse filosofe Martha Nussbaum (1998) laat zien dat de categorie van het 'goede leven' reeds bij Aristoteles aanwezig is in zijn overwegingen over de politieke betekenis van behoefte. In de Politica staan vele voorbeelden die een directe verbinding leggen tussen een oordeel of observatie over wat goed of gewenst menselijk gedrag is en de implicatie hiervan voor goed beleid. $\mathrm{Er}$ is in deze voorbeelden steeds sprake van een idee van een goed menselijk leven, een idee dat rijker wordt ingevuld dan momenteel gebruikelijk is. Nussbaum constateert dat Aristoteles, in tegenstelling tot de huidige liberale opvattingen, uitgaat van een inhoudelijke visie op het goede leven en ze noemt dat 'a thick vague conception of the good' (p.138) die afwijkt van bijvoorbeeld van de 'thin theory' van Rawls. "This priority of the good is the most conspicuous difference between the Aristotelian conception 
and all major liberal theories." (p.138) Als we denken over behoefte en het goede leven moeten we zowel 'breed' als 'diep' gaan. Breed, omdat het niet alleen een elite mag betreffen maar elke burger. Het gaat erom alle burgers een minimum aan voorwaarden te verschaffen waardoor het goede leven mogelijk is. Diep, omdat het niet slechts de gebruikelijke categorieën (voedsel, werk) maar het geheel van aspecten van het goede leven betreft. In de jaren ' 80 heeft Nussbaum deze opvattingen over behoefte uitgewerkt, samen met de eerder genoemde Amartya Sen, in wat zij de Human Capabilities Approach noemen. Deze gaat uit van een bredere opvatting van ontwikkeling dan de puur economische en van een positieve opvatting van vrijheid ('vrij om te...') in plaats van de gebruikelijke liberale negatieve formulering ('vrij van...'). (Nussbaum en Sen, 1993) Zij formuleren tien vrijheden die een richting geven voor concrete beleidsbeslissingen (Nussbaum 2000).

\section{de maakbaarheid van behoeften}

De vraag is dan: als behoeften zo bepalend zijn voor de mogelijkheid van duurzame ontwikkeling, hoe moet een onderzoeksprogramma naar de maakbare behoefte er dan uitzien? Wat is de plek waar het beoordelen en ontwerpen van behoeften kan gebeuren? Filosofisch, conceptueel, praktisch, ethisch, politiek? Ik zie hier twee lijnen voor me, een empirische en een normatieve. In de eerste plaats is het van belang om inzicht te krijgen in de verschillende fasen van behoeftevorming, zoals ik dat hierboven in grove lijnen heb geschetst. Hoe werkt de productie van de behoeften in gevallen die waarschijnlijk elk een eigen dynamiek vertonen:

(i) consumentenproducten, die direct zichtbaar zijn en besproken worden;

(ii) procestechnologieën, die nieuwe producten mogelijk maken maar zelf niet als zodanig op de consumentenmarkt verschijnen; 
(iii) infrastructuur, systemen die ondersteunend zijn voor circulatie van goederen en ideeën;

(iv) 'enabling technologies', zoals ICT, nanotechnologie of genomics: technologieën die niet als zodanig op de markt komen maar wel een grote stempel zetten op producten en diensten.

De tweede lijn betreft een normatieve vraag: welke behoeften kunnen we ons veroorloven? Als er al een meer democratische, minder mimetische, minder ongecontroleerde vorm van behoeftevorming mogelijk zou zijn, dan niet achter een bureau maar ingebed in bestaande processen. $\mathrm{Er}$ is al een halve eeuw ervaring met Technology Assessment (TA), het inschatten van technische verandering in de hoop besluitvorming te beïnvloeden en te verbeteren. Was er in eerste instantie aandacht voor het voorspellen van effecten, later werd duidelijk dat technologische ontwikkeling zo niet werkt en ook besluitvorming zo niet werkt. In reactie hierop zijn vele varianten naar voren gekomen, zoals Interactive Technology Assessment (Grin e.a. 1995) en Constructief Technology Assessment (Rip e.a. 1995) . Het voert nu te ver om alle details te bespreken, maar centraal in deze staat het idee van inspraak van betrokkenen, het belang van bewustwording. Volgens de evolutionaire inzichten is technische ontwikkeling nooit een kwestie van go/no go, maar zijn er voortdurend beslispunten, die te verbeteren zijn met TA.

Twee aanpassingen van de TA-praktijk zou ik willen voorstellen, een gematigde en een radicale. De gematigde aanpassing is dat in de aspecten die bestudeerd en besproken worden ook de vraag gesteld wordt welke behoeften mogelijkerwijs worden gecreëerd. In het Utrechtse TA-onderzoek naar Lab-on-a-Chip, bijvoorbeeld, is deze vraag soms naar voren gekomen: is het wenselijk dat consumenten zelf thuis geavanceerde metingen doen om hun gezondheid te checken. Het is denkbaar, maar is het wenselijk om deze mogelijke nieuwe behoefte te scheppen? In de serie workshops die Rutger van Merkerk (2007) heeft 
georganiseerd voor zijn promotieonderzoek kwam naar voren dat zoiets niet wenselijk werd geacht door huisartsen en verzekeraars.

Een radicalere aanpassing van TA is om proactief een visie op het goede leven te formuleren en op mogelijke technologieën die hieraan bijdragen. Een bezwaar van bestaande vormen van Technology Assessment is dat deze pas in beeld komen indien er reeds een technologische optie als beloftevol in de schijnwerpers staat; denk aan de gevallen van genomics of nanotechnologie. En als het als beloftevol geldt, zal het onderdeel worden van de dynamiek die ik hierboven geschetst heb: van belofte naar vereiste naar behoefte. Bezwaren of alternatieven worden dan al snel geduid als een blokkade; er dreigt al snel het gevaar van polarisatie tussen degenen die kennelijk voor of kennelijk tegen de technologie zijn, hoe kunstmatig het onderscheid vaak ook is (Rip en Talma 1998). Enigszins provocerend zou je de bestaande vormen TA reactief kunnen noemen: het wacht tot een technologie in beeld is en reageert dan pas. Het is zou ook mogelijk moeten zijn om proactief te zijn en uit te gaan van de vraag welke behoeften we in het leven zouden willen roepen - een 'backcasting' (Quist 2007) van behoefte, als het ware.

Een inspirerende invalshoek is die van de lerende organisatie, zoals die door Chris Argyris, Peter Senge, Otto Scharmer en anderen is ontwikkeld. Hierin worden inzichten uit de systeemtheorie gecombineerd met onderzoek naar de diepere drijfveren van gedrag in organisaties. In hun boek Presence: An Exploration of Profound Change in People, Organizations, and Society (2005) gaan de auteurs in op de mogelijkheid en kracht van reflectie. Hun diagnose is dat veel belangrijke veranderingen in organisaties stagneren omdat de verschillende betrokkenen hun belang te eng definiëren en te snel overgaan naar een compromis tussen de verschillende gezichtspunten. Het loont, volgens de auteurs, om eerst nauwgezet een beeld van het systeem te maken waarin elke betrokkene herkent wat zijn of haar verantwoordelijkheid is. Als de organisatie bijvoorbeeld het oplossen van urgente knelpunten en het blus- 
De makbare behoefte: naar een filosofie van duurzame ontwikkeling

sen van brandjes beloont, is er een belang om brandjes in stand te houden. Pas wanneer het systeem doorzien wordt en wanneer betrokkenen hun aandeel herkennen en erkennen (niet zozeer in morele maar causale zin), dan is een volgende stap in lerend vermogen van een organisatie mogelijk.

Voor een grotere eenheid dan een organisatie is dit een lastiger opgave. Toch lijkt het niet onmogelijk. In Presence bespreken de auteurs een leerproces in Main regio ten noorden van Frankfurt waar de gezondheidszorg voor een groot deel wordt verzorgd door private partijen onder toezicht van het Gesundheitsministerium. Het onderzoek van Otto Scharmer en collega's, in opdracht van een organisatie van artsen, toonde aan dat patiënten en artsen elkaar vasthielden in een patroon waar niemand tevreden over was: patiënten handelden vanuit het idee dat artsen hun lastig vonden en hen als kinderen behandelden, artsen vonden patiënten te veel klagen en onvolwassen. Een doorbraak was pas mogelijk toen zowel artsen als patiënten hun prima facie belangen en definities konden overstijgen en hun aandeel konden zien in het systeem dat ze samen in stand hielden. Er zijn in deze aanpak duidelijke verbanden met de traditie van systeem- of gezinstherapie, waarbij voortgang mogelijk wordt als er zicht ontstaat van wat er op systeemniveau gaande is (Lange, 2006). Een collectief leerproces, een collectieve zelfopvoeding, gaat het werken? Het zou naïef zijn volmondig ja te zeggen, maar een volmondig nee is dat evenzeer.

Eerder formuleerde ik de centrale vraag van een filosofie van duurzame ontwikkeling als de vraag welke behoeften we ons kunnen veroorloven. De zoektocht naar wat behoeften zijn en doen, zo hebben we gezien, is geen tijdloze vraag, maar verstrengeld met de innovatiedynamiek. Behoeften veranderen ingrijpend met technologische ontwikkeling op een wijze waarbij we automatisch achter de feiten aanlopen. Opvallend is ook dat het vaststellen van behoeften maatschappelijk weinig zichtbaar is. De vraag wat onze behoeften zijn wordt óf uitbesteed aan professionals, zoals architecten of woningcorporaties, of simpelweg opge- 
vat als uitkomst van marktwerking: als we een iPpad kopen hebben we er dús behoefte aan, als we het niet kopen dús niet. Toch moeten we de vraag naar wie of wat onze behoefte maakt dwingender stellen als we huidige generaties willen voorzien in hun behoefte zonder de mogelijkheden in gevaar te brengen van toekomstige generaties om hun behoeftes te vervullen. Bij deze vragen lijkt het beter om niet te starten met subjectieve preferenties, maar om behoeften te relateren aan noties van het goede leven. Mijn voorstel is dan ook om 12 november, als dag nadat duurzaamheid, respect, wetenschap en carnaval uitvoerig aan bod zijn geweest, te kronen tot dag van het goede leven.

\section{dankwoord}

Tot slot wil ik graag enkele woorden van dank uitspreken. In de eerste plaats gaat mijn dank uit naar de Stichting Socrates, die deze nieuwe leerstoel ingesteld heeft, de leerstoel 'filosofie van duurzame ontwikkeling vanuit een humanistisch perspectief'. Ik dank ook voor het vertrouwen dat ik heb gekregen om deze te als eerste te bezetten. Ook dank ik de Universiteit Maastricht en de faculteit Humanities and Sciences voor hun aandeel in dit avontuur.

Collega's van ICIS, het International Center for Integrated Assessment and Sustainable Development, dank voor de enorme hartelijkheid waarmee jullie mijn aanwezigheid hebben verwelkomd. Jullie hebben een vrolijke en vruchtbare onderzoekscultuur waar ik mij nu al thuis voel. In het bijzonder dank ik Pim Martens, die geijverd heeft voor de instelling van de leerstoel en mij enthousiast wegwijs maakt in de nieuwe omgeving.

Ik wil ook de Faculteit Geowetenschappen van de Universiteit Utrecht danken voor de samenwerking die met mijn bezetting van de leerstoel mogelijk wordt gemaakt. Het Utrechtse Copernicus Instituut voor Duurzame Ontwikkeling heeft vergelijkbare ambities als het Maastrichtse 
ICIS en samenwerking kan beiden sterker maken. Het dit jaar gehonoreerde NWO-project Inspirator waar onderzoekers uit Utrecht en Maastricht in deelnemen is een eerste voorbeeld van deze mogelijkheden. Vrienden en collega's van de groep Innovatiewetenschap, jullie vormen een stevige en inspirerende thuisbasis. De verschillende invalshoeken en persoonlijkheden, gecombineerd met de veeleisende aanwezigheid van studenten leveren een vruchtbare plek om te werken. In het bijzonder dank ik de promovendi, die mij met nieuwe vragen bestoken: Laurens, Sjoerd, Shu, Yvonne, Nora.

Een bijzonder woord van dank geldt zeker voor Arie Rip, mijn promotor en vriend. Je hebt me het plezier in intellectuele vergezichten laten zien, maar ook de ambachtelijkheid van onderzoek. Ik heb zoveel van je geleerd.

Saskia, het is heerlijk om dit alles met jou te kunnen delen. Vanaf het eerste moment van onze relatie, 20 jaar geleden, in de FWT groep van de Universiteit Twente hebben we onze intellectuele zoektocht kunnen delen. Waar ik op mijn werk het me nog wel eens kan veroorloven om begripsmatig wat in te zakken, is dat thuis zeker niet het geval. Daar is blijvende scherpte geboden, dank je wel. Je hebt me daarnaast steeds gestimuleerd om niet tevreden te zijn met interessante observaties, maar ook de normatieve kant niet te vergeten. Jowan en Carina, ook jullie wil ik hier noemen, hoewel jullie daar misschien nu geen behoefte aan hebben.

En ja, dank ook voor mijn ouders, Guus en Nelly. Ik zie steeds beter waar mijn kritische zin, maar ook mijn onbekommerde vertrouwen vandaan komt. Toen mij op jonge leeftijd de vraag gesteld werd wat ik later wilde worden was mijn antwoord tot jullie schrik: 'een gewone meneer, net als mijn vader'. Welnu, Guus, ik kan nu als bijzonder hoogleraar trots melden dat het ons geen van beide gelukt is een gewone meneer te worden. 
Tot slot wil ik mijn nieuwe collega en kamergenoot René Kemp bedanken. Onze manieren van denken en kijken vinden snel een verbinding ik ben dan ook blij dat we deze bijzondere middag kunnen delen en de feestvreugde verdubbelen. Ik geef het woord nu graag aan jou.

Ik heb gezegd. 


\section{Literatuur}

Achterhuis, H. (1988), Het rijk van de schaarste, Baarn: Ambo

Achterhuis, H. (2010), De utopie van de vrije markt, Rotterdam: Lemniscaat.

Albert de la Bruheze, A. en R. Oldenziel (eds.) (2009), Manufacturing Technology, Manufacturing Consumers, Amsterdam: Aksant.

Basalla, G. (1988), The evolution of technology, Cambridge: Cambridge University Press.

Blackwell, R., P.W. Miniard en J. Engel (2001) Consumer Behavior, Mason, Ohio: South Western Thomson Learning.

Brock, G. (ed.) (1998) Necessary Goods. Our responsibility to Meet Other's Needs. Lanham, MD: Rowman \& Littlefield.

Bijker, W.E. (1995), Bicycles, Bakelites, and Bulbs. Toward a Theory of Sociotechnical Change, Cambridge: MIT Press.

Brundtland Report (1987), Our Common Future, Oxford: Oxford University Press.

Doyal, L., \& Gough, I. (1991). A theory of human need. New York: Guilford Press.

Drenthen, M. \& P. Kockelkoren (1999), 'Het milieu van de filosofen: 20 jaar milieufilosofie in Nederland' Filosofie \& Praktijk, vol. 20 (4) 191-197.

Drucker P.E. (1954), The Practice of Management, New York: Harper \& Row.

Ellul, J. (1954), The Technological Society, New York: Random House

Ellul, J. (1977), The Technological System, New York: Continuum

Graber, F. (2007), Inventing needs: Expertise and water supply in late eighteenth- and early nineteenth-century Paris. British Journal for the History of Science, 40(3), 315332.

Grin J. en R. Hoppe (1995). 'Toward a Comparative Framework for Learning from Experiences with Interactive Technology Assessment', Industrial and Environmental Crisis Quarterly, Vol. 9 (1), 99-120.

Hamilton, L. (2003), The Political Philosophy of Needs. Cambridge: Cambridge University Press.

Searle, J. (1962), How to do Things with Words, Oxford: Clarendon.

Kates, R.W. e.a. (2001), Sustainability Science, Science, Vol 292 (5517), 641-642.

Lange, A. (2006), Gedragsverandering in gezinnen. Cognitieve gedrags- en systeemtherapie, Groningen: Martinus Nijhoff.

Levitt, T. (1960). "Marketing Myopia". Harvard Business Review.

Korthals, M. (1994), Duurzaamheid en democratie, Meppel: Boom.

McGee, M.C. (1980), The "ideograph": A link between rhetoric and ideology. Quarterly Journal of Speech, 66, 1-16.

Nussbaum, M.C. (1998), 'Aristotelian social democracy', in Brock, G. (ed.) Necessary Goods. Our responsibility to Meet Other's Needs. Lanham, MD: Rowman \& Littlefield, 135-157.

Nussbaum, M. C. (2000), Women and Human Development: The Capabilities Approach, Cambridge: Cambridge University Press.

Nussbaum, M.C., en Sen, A. (1993), The Quality of Life. Oxford: Clarendon Press.

Nye, D. (1996), American Technological Sublime, Cambridge: MIT press. 
Ortega Y Gasset, J. (1965), Bespiegelingen over leven en denken, historie en techniek, Den Haag: Leopolds Uitgeversmij.

Oudshoorn, N. E. J. and Pinch, T.J. (2003) How Users Matter. The Co-construction of Users and Technology. Cambridge, Massachusetts: MIT Press.

Poulter, S and C. Bates (2010), 'Apple iPad is finally here...but will anyone want to buy one?', Mail Online, 28th January 2010.

Quist, J. J., (2008) Backcasting For A Sustainable Future. Delft: Eburon. PhD dissertation Delft University of Technology

Rawls, J. (1971), A theory of justice, Cambridge, Mass: Harvard University Press.

Rip, A., T. Misa, en J. (eds.) (1995) Managing Technology in Society: The Approach of Constructive Technology Assessment, Pinter.

Rip, A. en Talma, A.S. (1998), Antagonistic patterns and new technologies, in C. Disco and B. van der Meulen: Getting New Technologies Together: Studies in making Sociotechnical Order. Berlijn: Walter de Gruyter, 299-323.

Silverstone R en R. Hirsch, (eds.) (1992), Consuming Technologies : Media and information in domestic spaces. London/New York: Routledge.

Sen, A. (1985), Commodities and capabilities. North Holland, Amsterdam.

Senge, P. M. (1990), The Fifth Discipline: The Art and Practice of the Learning Organization. New York: Doubleday.

Senge, P., C.O. Scharmer, J. Jaworski and B.S. Flowers (2005), Presence: An Exploration of Profound Change in People, Organizations, and Society, New York: Double Day

Soper, K. (2006). Conceptualizing needs in the context of consumer politics. Journal of Consumer Policy, 29(4), 355-372.

Utterback, J.M. (1993), Mastering the Dynamics of Innovation, Boston: Harvard Business School Press.

Van de Wal, G.A., (1996), De omkering van de wereld; Achtergronden van de milieucrisis en het zinloosheidsbesef, Baarn.

Van Lente, H. (1993), Promising Technology. Dynamics of Expectations in Technological Developments, Delft: Eburon. PhD Dissertation University of Twente.

Van Lente, H. en A. Rip (1998), 'The Rise of Membrane Technology. From Rhetorics to Social Reality', Social Studies of Science, Vol.28(2), 221-254.

Van Lente, H. (2000). Forceful futures: From promise to requirement. In N. Brown, B. Rappert \& A. Webster (Eds.), Contested futures. A sociology of prospective technoscience, Aldershot: Ashgate Publishing, 43-64.

Van Lente, H. (2002), 'Techniek en het goede leven: de filosofie van Ortega y Gasset', Filosofie, Vol. 11 (6), 2002, 55-58.

Van Lente, H. en J. van Til (2008), 'Articulation of sustainability in the emerging field of nanocoatings', Journal of Cleaner Production 16, 967-976.

Van Lente, H. en S. Bakker (2010) 'Competing expectations: the case of hydrogen storage technologies', Technology Analysis \& Strategic Management. Vol 22 (6), 693-709.

Van Merkerk, R.O. (2007), Intervening in emerging nanotechnologies: a CTA of Lab on a chip technology, Utrecht Universty, PhD Dissertation 
Van Praag, J. (1996), Grondslagen van humanisme: inleiding tot een humanistische levensen denkwereld, (vierde druk; eerste druk 1978), Meppel: Boom.

Vermeersch, E. (1988), De Ogen van de Panda. Een milieufilosofisch essay, Brugge: Van de Wiele.

Ware, A. en E.R. Goodin (1990), Needs and Welfare, London: Sage.

Williams, R., Stewart, J, Slack, R.,(2004) Social Learning in Technological Innovation, Cheltenham, Edward Elgar.

Wyatt, S., Henwood, R., Hart, A. and Smith, J. (2005) The digital divide, health information and everyday life, New Media \& Society, Vol 7(2), 199-218.

Ytrehus, S. (2000), Interpretation of housing needs. A critical discussion. Housing, Theory and Society, 17(4), 166-174.

Ziegler, J. (2010), De haat tegen het Westen. Het verhaal van de economische oorlog tussen arme en rijke landen, Uitgeverij Balans. 